\title{
The application of potato starch effluent causes a reduction in the photosynthetic efficiency and growth of Scots pine (Pinus sylvestris L.)
}

\author{
Marcin Koprowski ${ }^{1}$ - Iain Robertson ${ }^{2} \cdot$ Tommy H. G. Wils $^{3} \cdot$ Hazem M. Kalaji ${ }^{4}$
}

Received: 29 October 2014/Revised: 8 May 2015 / Accepted: 18 May 2015/Published online: 4 June 2015

(C) The Author(s) 2015. This article is published with open access at Springerlink.com

\begin{abstract}
Key message The high concentration of $\mathrm{N}$ and $\mathrm{K}$ caused a weakening of physiological conditions of the trees. Application of $N, P$ and $K$ from starch effluent is not a suitable method of waste management.

Abstract Since 1984, potato starch effluent has been applied to trees in the Iława Forest Inspectorate to promote the biological utilization of this waste product containing high amounts of nitrogen $(\mathrm{N})$, phosphorus $(\mathrm{P})$ and potassium $(\mathrm{K})$. We examined the tree rings of Scots pine (Pinus sylvestris $\mathrm{L}$.) to study the effect of intensive fertilization on tree rings. A total of 120 samples were taken from three sites representing a fertilized and unfertilized area and trees growing at a control site, outside the forest waste water system. We found that February and March temperature influenced the growth of tree rings. We used multiple
\end{abstract}

Communicated by U. Luettge.

Electronic supplementary material The online version of this article (doi:10.1007/s00468-015-1228-x) contains supplementary material, which is available to authorized users.

Marcin Koprowski

koper@umk.pl

1 Department of Ecology and Biogeography, Faculty of Biology and Environment Protection, Nicolaus Copernicus University, Lwowska 1, 87-100 Toruń, Poland

2 Department of Geography, College of Science, Swansea University, Swansea SA2 8PP, UK

3 Department of Geography, Institute for Teacher Training, Rotterdam University of Applied Sciences, Rotterdam, The Netherlands

4 Department of Plant Physiology, Faculty of Agriculture and Biology, Warsaw University of Life Science, Warsaw, Poland regression to investigate the influence of $\mathrm{N}, \mathrm{P}$ and $\mathrm{K}$ concentration, the amount of waste water and February and March temperature upon tree growth. Akaike information criterion (AIC) model selection was applied to choose the most influential factors upon growth, and additional multiple regression analyses were performed for two subsets of variables. Trees growing on the unfertilized site responded positively to $\mathrm{N}$ content and negatively to $\mathrm{P}$ content. For the fertilized site, the high concentration of $\mathrm{N}$ and $\mathrm{K}$ together with decreasing volume of waste water caused a growth decline. Trees from fertilized area also showed a decrease in their photosynthetic efficiency.

Keywords Tree rings - Chlorophyll fluorescence $\cdot$ Scots pine $\cdot$ Forest fertilization $\cdot$ Potato starch production $\cdot$ Forest wastewater treatment

\section{Introduction}

The production of potato starch needs approximately $15 \mathrm{~m}^{3}$ of water per tonne of starch (Peters 1972). The high volumes of waste water generated can lead to a conflict of interests with the local community. According to the existing regulations, the municipal waste water system should not be used to remove this high volume of waste. One solution is to distribute the water to a nearby forest (e.g. Iława Forest Inspectorate; Ciepielowski et al. 1999) or to use meadow plants to utilize waste water (e.g. meadows in Mątwica-Kupiski and Kupiski-Jednaczewo; Hawelke and Sokolowski 1999). Previous research found that pine forests should not be irrigated with waste water from potato starch processing plants because the effluents can damage the trees within a few years (Peters 1972). Contrary to these findings, waste water with a high starch content was 
applied to the Iława Forest Inspectorate from 1984 to 2012. The amount of nitrogen $(\mathrm{N})$, potassium $(\mathrm{K})$ and phosphorus $(\mathrm{P})$ in the waste water differed from year-to-year (data from the Chemirol Company Ltd.). Because Iława is a tourist attraction, the amount of effluent applied was limited to reduce the smell in the neighbouring regions.

The typical experiments with forest fertilization were conducted in the USA (Fox et al. 2007) and Scandinavia (Moller 1992). The fertilizers used in forestry are usually similar to those used in agriculture. The main aim of these experiments was to increase the average rate of wood production per unit of land (Smethurst 2010). Controlled fertilization in Scandinavia caused an increase in basal area growth with a fertilization interval of six years (Moller 1992). In case of pine plantations in the southern United States, fertilization with both $\mathrm{N}$ and $\mathrm{P}$ increased growth for $8-10$ years (Fox et al. 2007). Fertilization of forests also has disadvantages; the most visible of which is the change in vegetation as nitrogen-demanding plants will increase whilst plants adapted to nitrogen-poor sites will decrease (Moller 1992). Other negative effect of the over application of nitrogen is the disappearance of mycorrhiza. The symbiotic relationship between mycorrhiza and roots causes the mycelium (vegetative part of a fungus) to increase the absorption area of the root and protect the roots against pathogens (Oleksyn 1998).

In this study, waste water was applied to the same part of the forest every 7-8 days with maximum of ten applications in a season. The application of waste water started after the potato harvest which was usually at the beginning of September. The area of the experimental forest was 174 hectares, situated $7 \mathrm{~km}$ from the potato starch processing factory. The total length of the pipe system used to apply the effluent was in excess of $40 \mathrm{~km}$ (Marszałek A, personal communication). One of the aims of this study was to investigate the application of waste water containing $\mathrm{N}, \mathrm{P}$ and $\mathrm{K}$ upon the growth of Scots pine (Pinus sylvestris). Because the effect of climate on pine tree rings in Poland is well recognized (Szychowska-Krapiec 2010; Koprowski et al. 2012; Opała and Mendecki 2014), we compared also the relationships between climate and tree growth with other regions.

Chlorophyll fluorescence (ChlF) measurements have recently become a widely adopted to evaluate the impact of stress factors on photosynthesis (Kalaji et al. 2012). They represent a simple, non-destructive, inexpensive and rapid tool for analysing light-dependent photosynthetic reactions and for indirectly estimating chlorophyll content within the same sample tissue. Furthermore, ChlF measurements indirectly provide information about the physiological condition of plants. The technical advantages of ChlF approaches have made it a popular technique amongst plant breeders (e.g. for crop phenotyping and monitoring), biotechnologists, plant physiologists, farmers, gardeners, ecophysiologists and foresters (Kalaji et al. 2012). We applied these measurements to check if the waste water containing $\mathrm{N}, \mathrm{P}$ and $\mathrm{K}$ affect trees photosynthetic efficiency.

\section{Materials and methods}

\section{Site selection and sampling}

In order to check, the effect of forest fertilization we selected three sites. Sites 1 and 2 were located in the Forest Wastewater Treatment zone (FWT), whilst Site 3 was a control site, situated outside this zone. Trees growing at Site 1 were fertilized, whilst trees growing at Site 2 were unfertilized despite being located within the zone of Forest Wastewater Treatment (FWT) (Fig. 1). According to information provided by the Iława Forest District, the trees were approximately the same age, reaching about 80 years. The trees did not show any visible signs of disease. However, on the fertilized part of the study, the tree density was lower because of snag occurrence (Fig. 1). Using a standard $5 \mathrm{~mm}$ diameter Pressler borer, 120 cores were obtained from Scots pine trees growing at three different sites (40 cores from each site). Two core samples were taken from each tree, one from the west and another one from the east, at a height of approximately $1.30 \mathrm{~m}$ above the ground. The cores were prepared for measurements using standard dendrochronological procedures (Zielski and Krąpiec 2004).

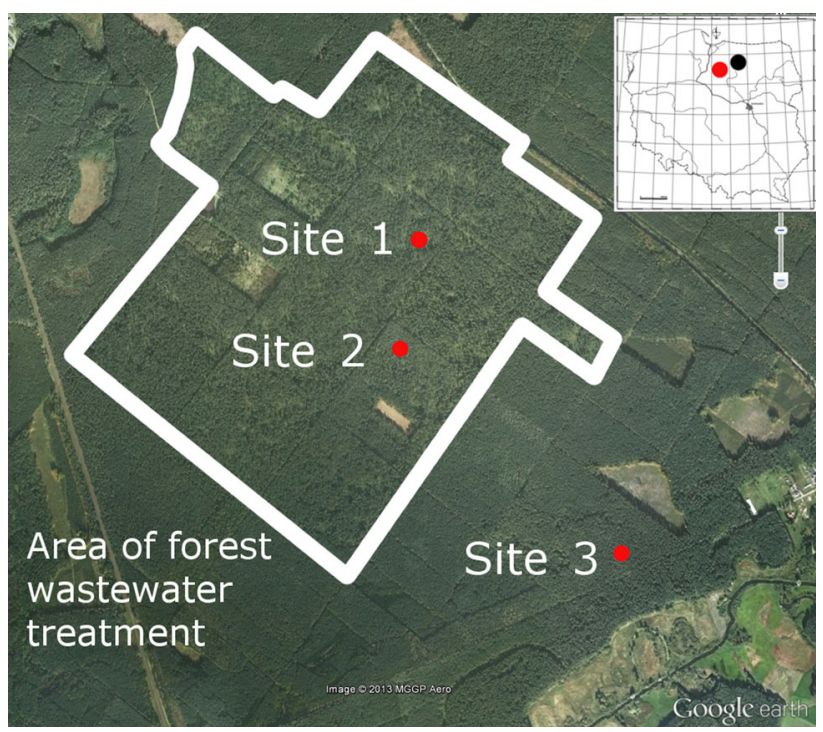

Fig. 1 Location of the research sites (red circle) and meteorological station (black circle) Site 1-fertilized, Site 2-unfertilized and Site 3 -control. A decrease in crown density due to fertilization is visible in fertilized area 


\section{Tree rings}

The sanded core samples were scanned at 1200 dpi resolution using a standard scanner (Epson Perfection V700 Photo). Basic tree-ring parameters were obtained from the measurement of ring widths to the nearest $0.01 \mathrm{~mm}$ using CooRecorder software combined with the related CDendro program (Larsson and Larsson 2013). Checks on crossmatching were carried out using COFECHA (Holmes 1983). Additionally, each sample was analysed by means of the skeleton plot method after Stokes and Smiley (1968). Initially, in order to analyse the effect of meteorological parameters on tree rings the long-term trends in tree rings were removed. The smoothing spline option of the dplR package (Bunn 2008) from R (R Development Core Team 2007) was used to detrend the temporal data series. The " $n$ year spline" at $2 / 3$ the wavelength of $n$ years was used, after Cook et al. (1990). The effect of outliers was minimized using Tukey's bi-weight robust method (Cook et al. 1990). A residual version of the chronology was built by pre-whitening after fitting an autoregressive model to the data using the Akaike information criterion (AIC) for variable selection (Bunn 2008). Additionally, the expressed population signal (EPS) was calculated as a measure of the common signal in the chronology (Wigley et al. 1984). The relationship between climate and tree rings was investigated for the common period of 1951-2011 using bootRes software (Zang and Biondi 2013). The climate data were taken from the nearest meteorological station in Olsztyn (60 km from the site).

Finally, the influence of selected climatic parameters, together with effluent data, was analysed. We applied multiple regression for selected climate parameters, $\mathrm{N}, \mathrm{P}$ and $\mathrm{K}$ concentration, and the amount of waste water. Waste water from the manufacture of starch essentially contains minerals, proteins, vitamins, phytates and glycoalkaloids (Kowalczewski et al. 2012, 2014; Mayer and Hillebrandt 1997; Vlachojannis et al. 2010). In order to select the most crucial factors determining tree-ring widths, AIC model selection was applied. At first all independent variables were used. However, as the concentration of $\mathrm{N}, \mathrm{K}$ and $\mathrm{P}$ is directly related to amount of waste water, we applied the regression model with following independent variables:

- Selected climate variables, N, P and K concentration

- Selected climate variables, N, P and K content and amount of waste water.

\section{Chlorophyll fluorescence}

In order to assess the physiological condition of the trees, the photosynthetic efficiency of photosystem II (PSII) was measured using a PocketPEA fluorometer (Hansatech
Instruments Ltd., UK). A total of 240 needle samples were obtained. Ten trees were selected at each site with eight samples (one sample is $2-3$ needles) taken from each tree. Taking into account the cardinal direction (north, south, west and east), four needles were obtained from the upper part of the crown and four needles were obtained from lower part of the crown. Following strict safety protocols, samples were obtained from living trees by shooting the branches with a double-barreled shotgun. The samples (2-3 needles located next to each other) were enclosed in the fluorimeter leaf clips, with a measuring cross section (measuring aperture) of $4 \mathrm{~mm}^{2}$, for 15-20 min to allow effective dark adaptation. A pulse of saturated $\left(3000 \mu \mathrm{mol} \mathrm{m}{ }^{-2} \mathrm{~s}^{-1}\right)$ red light with a peak wavelength $650 \mathrm{~nm}$ was applied for $1 \mathrm{~s}$ to measure chlorophyll fluorescence. PEA Plus V1.04 software was used to assess the physiological condition of the tree. As a measure of abiotic stress, we used the Fv/Fm ratio (Maximum Quantum Efficiency of Photosystem II). This parameter is accepted and widely used as reliable diagnostic indicator of plant photochemical performance (He et al. 1996; Valladares and Pearcy 1997; Maxwell and Johnson 2000; Kalaji and Guo 2008). ANOVA and Tukey's tests were applied to the resulting data. In this study, standard fluorescence parameters were obtained (Strasser et al. 2004; Kalaji and Guo 2008; Kalaji et al. 2011):

Fo minimal fluorescence (represents emission of molecules by excited chlorophyll $a$ into antennae structure of Photosystem II-PSII);

Fm maximal fluorescence (occurs when electron acceptor Qa is fully reduced);

Fv/Fm maximum quantum efficiency of PSII (this parameter is presented as a ratio of variable fluorescence/ $\mathrm{Fv}=\mathrm{Fm}-\mathrm{Fo} /$ to the maximum fluorescence value Fm)

Fv/Fo maximum primary yield of photochemistry of PSII (this parameter can provide an estimation of leaf photosynthetic capacity);

DF total-total driving force for photosynthesis, created by summing the partial driving forces for each of the several bifurcations (at the beginning of the fluorescence rise)

Area-the area above the chlorophyll fluorescence curve between Fo and Fm (reflecting the size of the plastoquinone pool).

\section{Results}

\section{Tree rings}

The measurement of ring widths revealed that over the common period (1944-2011), the mean tree-ring widths varied from $1.78 \mathrm{~mm}$ (Site 2) to $2.10 \mathrm{~mm}$ (Site 3). On the 
fertilized site (Site 1), the mean width was $1.84 \mathrm{~mm}$. During chronology construction, 18 representative samples from Site 1, 27 representative samples from Site 2 and 24 representative samples from Site 3 were selected. On each site, the Expressed Population Signal (EPS) was above the frequently applied threshold of 0.85 indicating a high degree of common coherence (Wigley et al. 1984). At Site 1, the EPS was 0.94; at Site 2, the EPS was 0.92 and at Site 3 , the EPS was 0.91. Analysis of site chronologies demonstrates that before fertilization with potato starch effluent in years 1944-1983, tree growth at all three sites was comparable with $t$ values between sites varying from 5.8 to 7.8 (Fig. 2). After fertilization commenced in 1984, there was a discrepancy between the ring widths from the fertilized and unfertilized trees. In the years 1984-2011, the $t$ value between fertilized (Site 1) and unfertilized trees (Site 2) and between fertilized (Site 1) and control trees (Site 3) was 3.3 and 3.0, respectively (Fig. 2). However, the visible discrepancy appears in 1986, two years after the fertilization started (Fig. 2).

Before we started to study the effect of fertilization, we investigated the climate influence as a basic factor determining tree growth. In the case of the control site (Site 3), the most crucial climate factor influencing growth was February and March temperature. Trees from the fertilized site (Site 1) demonstrated the positive influence of March temperature and May precipitation (Fig. 3a, b). Based upon these results, we applied the mean monthly February and
March temperature as independent variables. The influence of climate at all sites and the application of wastewater effluent on trees growing at Sites 1 and 2 were investigated using multiple regression (Table 1). The negative effect of the high concentration of $\mathrm{N}$ and $\mathrm{K}$ was noted on the fertilized trees (Table 1). Further, additional multiple regression analyses were performed (Tables 2, 3). Because there was no effect of fertilization on pine at Site 3 (control), we have excluded these trees from further analysis. After the first additional multiple regression, the positive effect of the high amount of water and the negative effect of the high amount of nitrogen were observed on trees growing at Site 1 (fertilized). In contrast, unfertilized trees growing inside the FWT area (Site 2) were positively affected by nitrogen content, and the reaction on late-winter temperature was also observed (Table 2). In the next multiple-regression model, after the treatment with high concentration of nitrogen and potassium, the negative dependence between tree growths was observed. Similar to the previous model, the unfertilized trees (Site 2) reacted positively to the increased nitrogen concentration (Table 3). The correlation between the tree rings width and amount of waste $\mathrm{N}$ and $\mathrm{K}$ concentration on the fertilized site (Site 1) confirmed the results of regression model and also showed that as the amount of water in the potato starch effluent decreased, tree growth declined. The negative effect of higher concentrations of nitrogen on ring widths was observed from 2002, and in case of potassium from 2000 (Fig. 4).
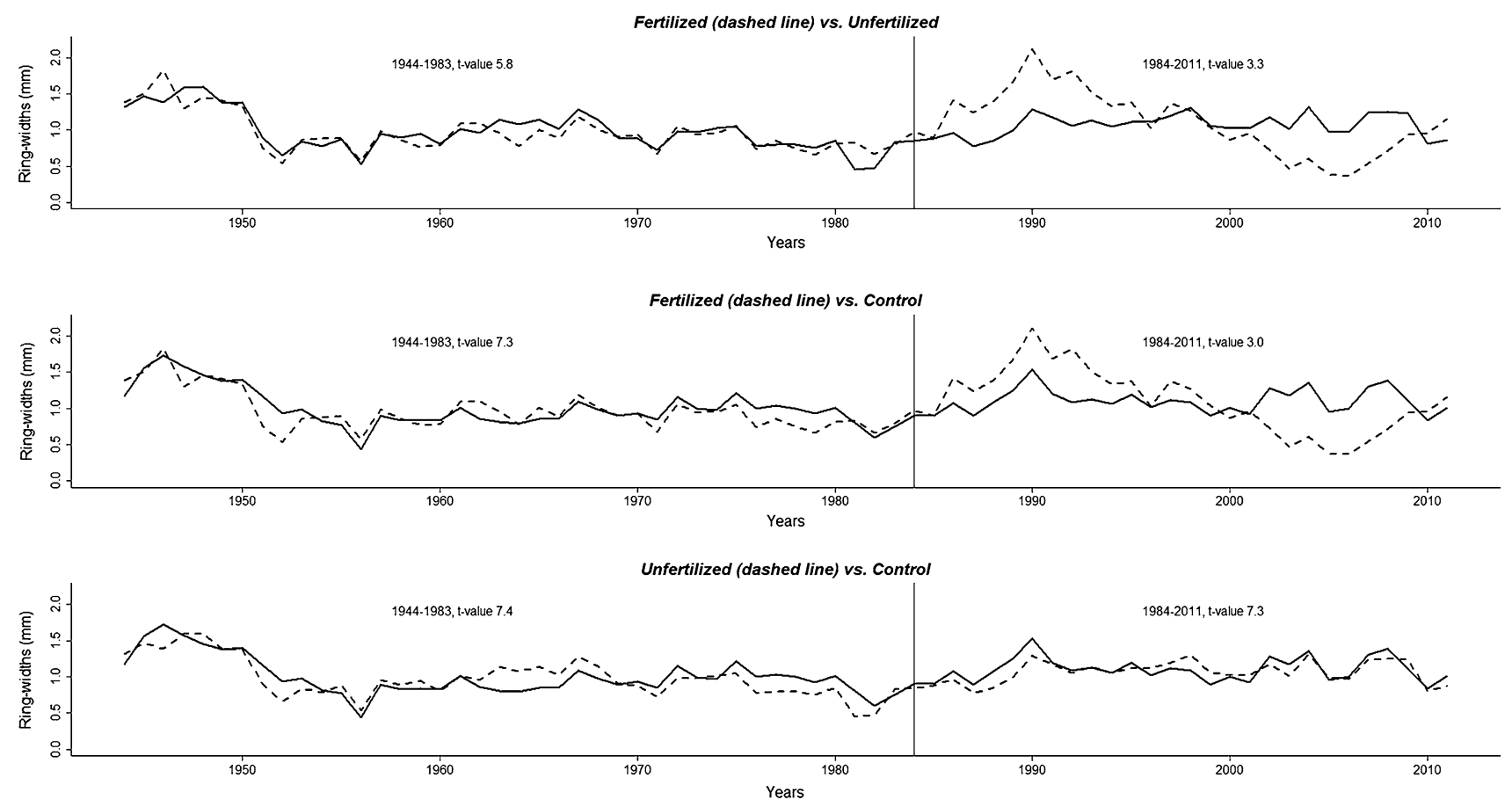

Fig. 2 Comparison of chronologies from three sites The vertical line in 1984 indicate start year of forest wastewater treatment growth of trees before 1984 is similar ( $t$ value from 5.8 to 7.4). Growth of fertilized trees differ $t$ value from 1984 in comparison with unfertilized and control trees is 3.3 and 3.0 , respectively 
(a)

Relationships between TRW and temperature

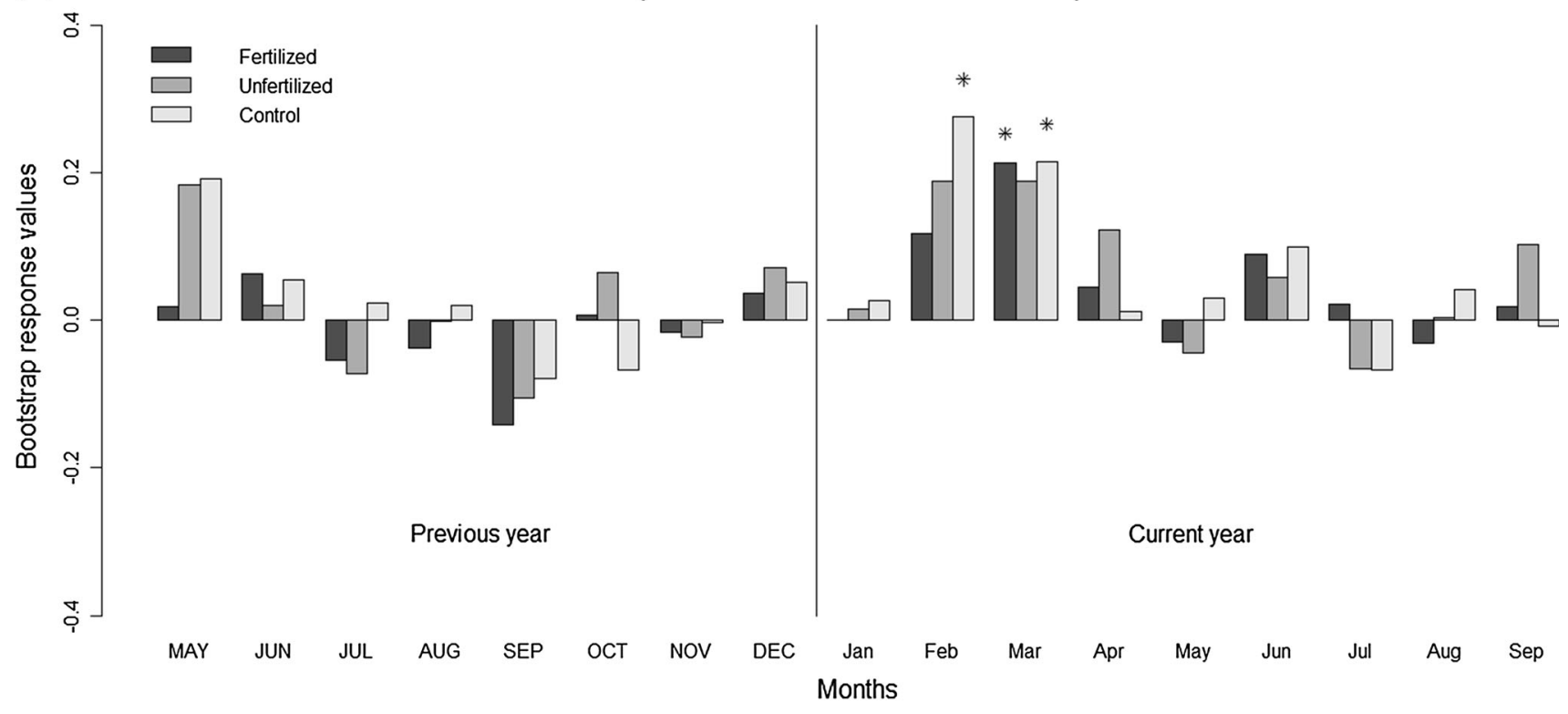

(b)

Relationships between TRW and precipitation

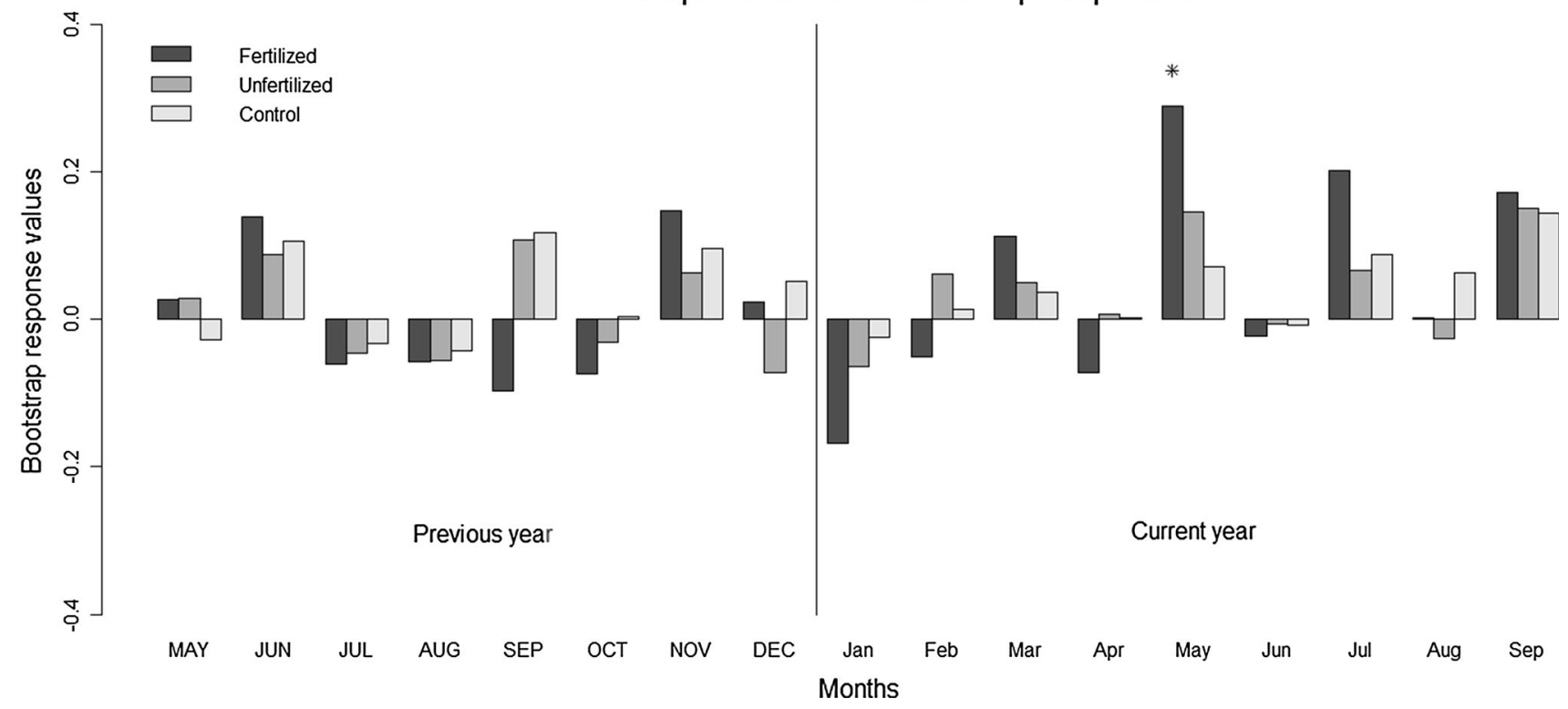

Fig. 3 a Relationships between growth and temperature on three sites Asterisk (*) indicate significance at $p<005$. Left side of each panel shows previous year and right side shows current year.

\section{Chlorophyll fluorescence}

The chlorophyll fluorescence transient curve (Kautsky Induction curve) (Fig. 5) shows that the values of most parameters were comparable for unfertilized trees (Sites 2 and 3), whilst they were lower for fertilized trees from Site 1 (Figs. 5, 6).

Comparison of the maximum quantum efficiency of Photosystem II $(\mathrm{Fv} / \mathrm{Fm})$ amongst the 3 sites shows the difference between fertilized trees and the rest of the trees b Relationships between growth and precipitation on three sites Asterisk (*) indicate significance at $p<005$. Left side of each panel shows previous year and right side shows current year

(Table 4). Fv/Fm of pines fertilized with waste water (Site 1) significantly differs from unfertilized pines (sites 2 and 3) (Table 5). Mean values of $\mathrm{Fv} / \mathrm{Fm}$ parameter in site 3 (control trees) and site 2 (unfertilized trees) were similar0.64 r. u. and 0.63 r. u., whilst in Site 1 (fertilized trees) was lower- $0.56 \mathrm{r}$. u.

The mean values of the $\mathrm{Fv} / \mathrm{Fm}$ parameter measured at all 3 sites were far from optimal. These results indicate that plants were influenced by some adverse environmental factor-such as low February temperature. The decrease in 
Table 1 Multiple regression model for years 1984-2009 for all data AIC values for multiple model for all and for selected independent variables, respectively

\begin{tabular}{|c|c|c|c|c|c|c|}
\hline & \multicolumn{4}{|c|}{ Forest wastewater plant } & \multicolumn{2}{|c|}{ Reference site } \\
\hline & \multicolumn{2}{|c|}{ Fertilized } & \multicolumn{2}{|c|}{ Unfertilized } & & \\
\hline & \multicolumn{2}{|c|}{ Multiple $R^{2}: 0.8377$} & \multicolumn{2}{|c|}{ Multiple $R^{2}: 0.7151$} & \multicolumn{2}{|c|}{ Multiple $R^{2}: 0.5434$} \\
\hline & $t$ value & $\operatorname{Pr}(>|t|)$ & $t$ value & $\operatorname{Pr}(>|t|)$ & $t$ value & $\operatorname{Pr}(>|t|)$ \\
\hline \multicolumn{7}{|l|}{ Wastewater parameters } \\
\hline Waste water $\left(\mathrm{m}^{3}\right)$ & -1.850 & 0.0799 & & & & \\
\hline Nitrogen content (mg) & 1.477 & 0.1560 & 2.762 & $0.0124 *$ & & \\
\hline Nitrogen concentration $\left(\mathrm{mg} / \mathrm{dm}^{3}\right)$ & -3.137 & $0.0054 * *$ & -1.265 & 0.2212 & & \\
\hline Potassium content (mg) & & & -1.387 & 0.1815 & & \\
\hline Potassium concentration $\left(\mathrm{mg} / \mathrm{dm}^{3}\right)$ & -4.014 & $0.0007 * * *$ & 1.561 & 0.1351 & & \\
\hline Phosphorus content (mg) & & & -2.347 & $0.0299 *$ & & \\
\hline \multicolumn{7}{|l|}{ Phosphorus concentration $\left(\mathrm{mg} / \mathrm{dm}^{3}\right)$} \\
\hline \multicolumn{7}{|l|}{ Climate parameters } \\
\hline February temperature & 1.521 & 0.1447 & & & 2.033 & 0.0538 \\
\hline March temperature & 1.917 & 0.0704 & 4.485 & $0.0003 * * *$ & 3.633 & $0.0014 * *$ \\
\hline
\end{tabular}

Fertilized $=-6883 /-7477$, Unfertilized $=-11,533 /-11,872$, Control site $=-9852 /-10,877$. Lower values indicate that the regression model for selected variables was fitted better. Asterisks and dot indicate level of significance: $* * * p<0.001, * * p<0.01, * p<0.05{ }^{\circ} p<0.1$

Table 2 Multiple regression model for years 1984-2009 for selected data AIC values for multiple model for all and for selected independent variables, respectively

\begin{tabular}{|c|c|c|c|c|}
\hline & \multicolumn{4}{|c|}{ Forest wastewater plant } \\
\hline & \multicolumn{2}{|c|}{ Fertilized } & \multicolumn{2}{|c|}{ Unfertilized } \\
\hline & \multicolumn{2}{|c|}{ Multiple $R^{2}: 0.623$} & \multicolumn{2}{|c|}{ Multiple $R^{2}: 0.6608$} \\
\hline & $t$ value & $\operatorname{Pr}(>|t|)$ & $t$ value & $\operatorname{Pr}(>|t|)$ \\
\hline \multicolumn{5}{|l|}{ Wastewater parameters } \\
\hline Waste water $\left(\mathrm{m}^{3}\right)$ & 5.293 & $0.0000301 * * *$ & & \\
\hline Nitrogen content (mg) & & & 3.453 & $0.002266 * *$ \\
\hline Potassium content (mg) & -5.068 & $0.000051 * * *$ & & \\
\hline Phosphorus content (mg) & & & -4.643 & $0.000125 * * *$ \\
\hline \multicolumn{5}{|l|}{ Climate parameters } \\
\hline February temperature & 1.763 & 0.0925 & & \\
\hline March temperature & 2.139 & $0.0444 *$ & 4.321 & $0.000276^{* * *}$ \\
\hline
\end{tabular}

Fertilized $=-5343 /-5686$, Unfertilized $=-11,812 /-12,018$. Lower values indicate that the regression model for selected variables was fitted better. Asterisks and dot indicate level of significance: $* * * p<0.001, * * p<0.01, * p<0.05,{ }^{\circ} p<0.1$
Fv/Fm was mostly due to a decrease of Fm rather than due to variation in Fo value (Fig. 5) and indicates that there was a blockage in electron transport and a reduction in the quantum yield of PSII. Nevertheless, the trees fertilized with waste water at Site 1 were characterized by significantly lower Fv/Fm (0.56 r. u.) than the unfertilized trees (Table 5). Such low Fv/Fm values indicate serious damage to photosystem II (PSII). Based on this fact and the reduction of other calculated chlorophyll fluorescence parameters, i.e. Area, DF and Fv/Fo, it can be assumed that fertilizing with waste water from potato starch processing may deteriorate physiological condition of pine trees.

\section{Discussion}

\section{Fertilization alters tree growth}

The first visible change of fertilization was related to the composition of forest vegetation. On the fertilized forest (Site 1), nitrogen-demanding plants dominate, whilst species such as Vaccinium, Melampyrum and Deschampsia from moderately rich or moderately poor-nutrient sites prevails on the unfertilized forest (Site 2) (Online Supplementary Material, Figure S2). In regularly fertilized forests, under the controlled conditions, the positive 
Table 3 Multiple regression model for years 1984-2009 for selected data AIC values for multiple model for all and for selected independent variables, respectively

\begin{tabular}{|c|c|c|c|c|}
\hline & \multicolumn{4}{|c|}{ Forest wastewater plant } \\
\hline & \multicolumn{2}{|c|}{ Fertilized } & \multicolumn{2}{|c|}{ Unfertilized } \\
\hline & \multicolumn{2}{|c|}{ Multiple $R^{2}: 0.8045$} & \multicolumn{2}{|c|}{ Multiple $R^{2}: 0.5583$} \\
\hline & $t$ value & $\operatorname{Pr}(>|t|)$ & $t$ value & $\operatorname{Pr}(>|t|)$ \\
\hline \multicolumn{5}{|l|}{ Wastewater parameters } \\
\hline Nitrogen concentration $\left(\mathrm{mg} / \mathrm{dm}^{3}\right)$ & -3.120 & $0.00517 * *$ & 2.861 & $0.00935^{* *}$ \\
\hline Potassium concentration $\left(\mathrm{mg} / \mathrm{dm}^{3}\right)$ & -3.597 & $0.00170 * *$ & & \\
\hline Phosphorus concentration $\left(\mathrm{mg} / \mathrm{dm}^{3}\right)$ & & & -1.358 & 0.18899 \\
\hline \multicolumn{5}{|l|}{ Climate parameters } \\
\hline February temperature & 1.993 & 0.05945 & 1.360 & 0.18827 \\
\hline March temperature & 2.270 & $0.03386 *$ & 3.102 & $0.00539 * *$ \\
\hline
\end{tabular}

Fertilized $=-7198 /-7393$, Unfertilized $=-10,938 /-11,131$. Lower values indicate that the regression model for selected variables was fitted better. Asterisks and dot indicate level of significance: $* * * p<0.001, * * p<0.01, * p<0.05{ }^{\circ}{ }^{\circ} \mathrm{p}<0.1$
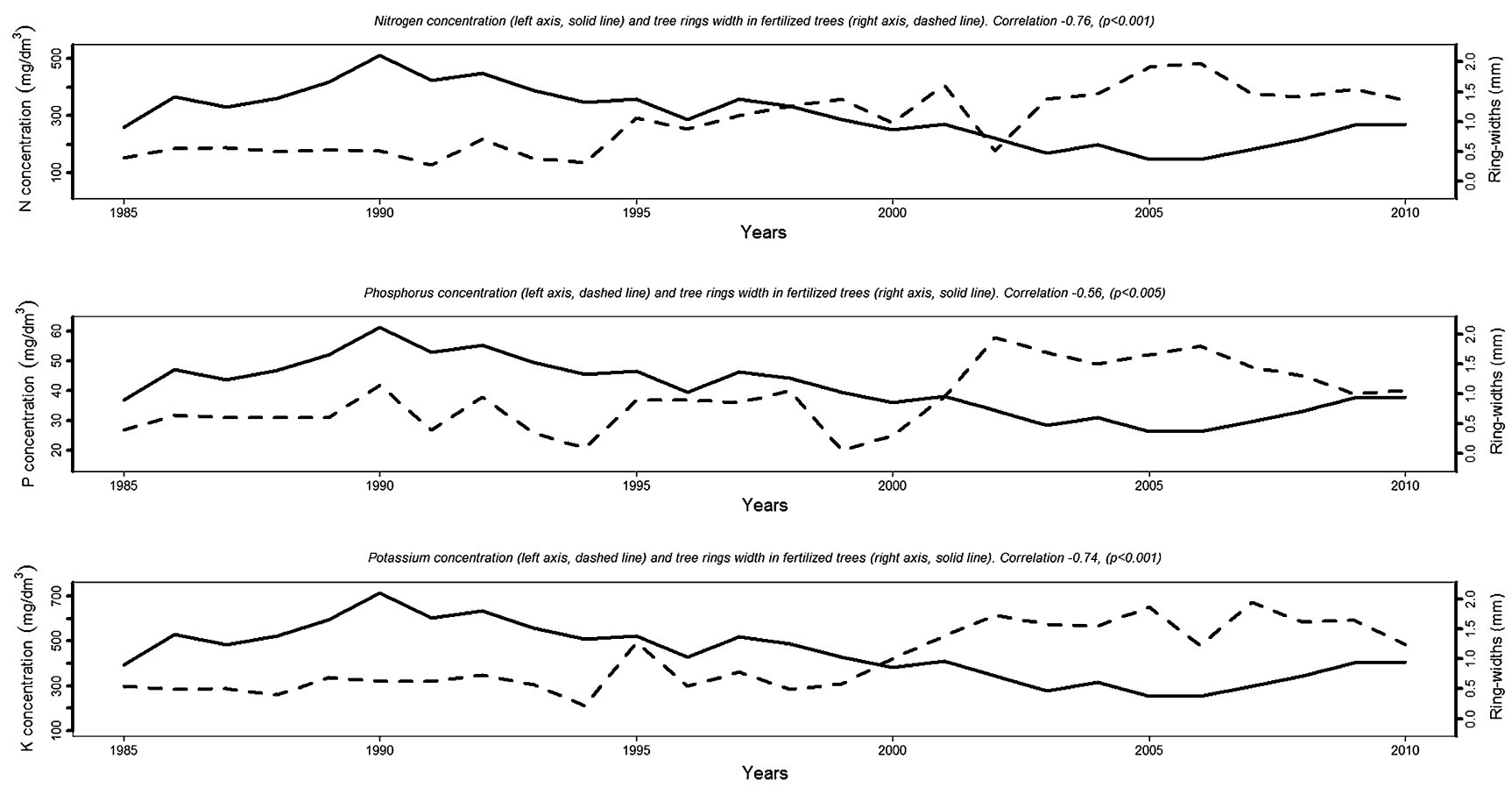

Fig. 4 Relationships between growth of fertilized trees and N, P and K. Concentration increase leads to growth decline

influence of fertilization on tree growth was observed (Moller 1992; Fox et al. 2007). Mellert et al. (2004) observed that improvements in $\mathrm{N}$ nutrition were reflected in positive trends in foliar $\mathrm{N}$ concentration and constant or increased needle mass (100-needle weight) or a positive trend in the foliar $\mathrm{N}$ content (product of foliar $\mathrm{N}$ concentration and needle mass). Our study revealed that after the nutrient concentration increased, a growth decline was observed. Analysis of tree rings illustrates the differences and similarities between fertilized (Site 1) and unfertilized (Sites 2 and 3) forests (Fig. 2). Our results confirm the previous study by Elhani et al. (2005), where there were no differences in tree growth rates before fertilization (Fig. 2). In the case of Fagus sylvatica, the increased tree growth disappeared during a period of drought (Elhani et al. 2005). Our study revealed that the reaction to climate, especially to precipitation in the years 1982-2011 differed between the fertilized (Site 1) and unfertilized (Site 2) trees. According to Glynn and Herms (2001), fertilization may also decrease drought stress tolerance. During the study period, an extreme drought occurred in 1992, which is reflected in spruce as a narrow rings (Koprowski 2013; 
Fig. 5 Fluorescence transient curve of pine (Pinus sylvestris) tress grown in 3 experimental area: fertilized, unfertilized and control, plotted on logarithmic scale of time. The shape of the curve is known as OJIP curve (see Kalaji et al. 2014)

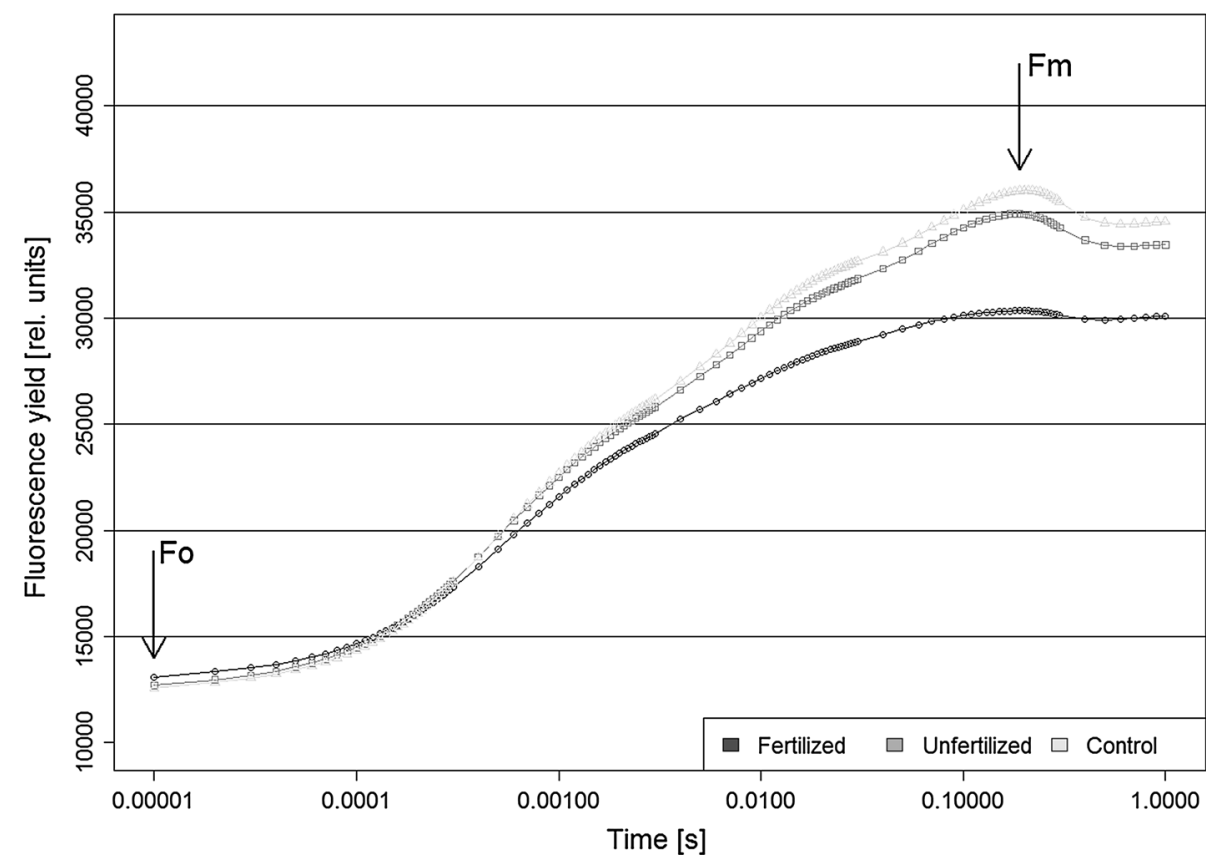

\section{Chlorophyll fluorescence parameters}

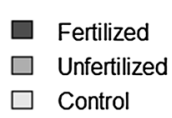

Fo

m

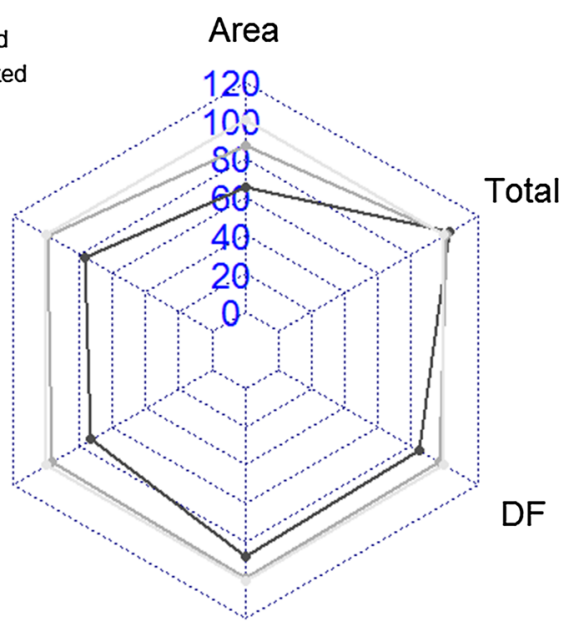

$\mathrm{Fv} / \mathrm{Fm}$
Fig. 6 A 'spider plot' of selected parameters characterizing behaviour of photosystem II of pine (Pinus sylvestris) tress grown in 3 experimental area: fertilized, unfertilized and control. (See the table of Nomenclature for the meaning of the symbols and the parameters). All values are shown as percent of control (control plants $=100)$

Vitas 2002) and 2003 (Sasim and Mierkiewicz 2005). In our case, the effect of drought stress in tree rings was not observed. The reason for the difference is species' response is that pine is more sensitive to the temperature of February and March. Previous studies reported the effect of temperature at the end of winter is the most important factor in determining pine growth in northern Poland (Zielski et al. 2010). Our findings confirmed the different relationships
Table 4 Results of ANOVA for Fv/Fm measurements (maximum quantum efficiency of PSII)

\begin{tabular}{lcllll}
\hline & $\begin{array}{l}\text { Sum of } \\
\text { squares }\end{array}$ & $\begin{array}{l}\text { Degrees } \\
\text { of } \\
\text { freedom }\end{array}$ & $\begin{array}{l}\text { Mean } \\
\text { square }\end{array}$ & $F$ & $p<0.05$ \\
\hline $\begin{array}{c}\text { Between } \\
\text { group } \\
\text { variation }\end{array}$ & 0.317308 & 2 & 0.158654 & 25.85 & $6.99 \mathrm{e}-11$ \\
$\begin{array}{l}\text { Within } \\
\text { group } \\
\text { variation }\end{array}$ & 1.45456 & 237 & 0.00613739 & & \\
Total & 1.77187 & 239 & & & \\
\hline
\end{tabular}

High $F$ value indicates that one of the mean values of measurements differ

between the growth of fertilized (Site 1) and unfertilized (Site 2) trees. The strong integration in forest site conditions may lead to divergence problem which may be anthropogenic in nature (D'Arrigo et al. 2008).

\section{Fertilization alters tree physiological condition}

Although enhanced $\mathrm{N}$-supply may increase plant growth, future responses have been largely studied within the context of $\mathrm{N}$ limitations to plant growth at elevated atmospheric $\mathrm{CO}_{2}$ concentrations (Reich et al. 2006; Luo et al., 2004). It has been speculated that increased nitrate pollution may contribute towards the divergence problem (Briffa et al. 1998; D'Arrigo et al. 2008) which is reflected in the recent decline in tree-ring sensitivity to temperature. 
Table 5 Results of Tukeys test values show that maximum quantum efficiency of PSII on fertilized trees is significantly lower than on unfertilized and control

\begin{tabular}{llll}
\hline$Q / p<0.05$ & Site 1 & Site 2 & Site 3 \\
\hline Site 1 & & $2.176 \mathrm{e}-05$ & $2.175 \mathrm{e}-05$ \\
Site 2 & 8.237 & & 0.7405 \\
Site 3 & 9.282 & 1.045 & \\
\hline
\end{tabular}

The first 15 years of fertilization revealed positive effect on tree-ring widths (Fig. 2). This finding is similar to other observations (Binkley et al. 1994; Moller 1992). The increased $\mathrm{N}$ and $\mathrm{K}$ concentration caused a growth decline (Fig. 4; Tables 1, 2, 3). From 1999, the potato starch processing factory started to reduce water usage causing the relative $\mathrm{N}, \mathrm{P}$ and $\mathrm{K}$ concentration in the effluent to increase (Marszałek A, personal communication). One of the reasons of growth decline may be the effect of $\mathrm{N}$ and $\mathrm{K}$ on mycorrhiza. Our results are difficult to compare with other studies. First, the primary aim of the Forest Wastewater Treatment (FWT) experiment was the biological utilization of waste effluents, whilst other studies focused on typical fertilization practice on forest plantations often with different dose rates. For example, in studies about the effect of $\mathrm{N}$-free fertilization on ectomycorrhiza in Sweden, in years 1988-1989 the amount of $\mathrm{K}$ applied was $43 \mathrm{~kg} \mathrm{ha}^{-1}$ (Kårén and Nylund 1996), yet in our case, in the year 1988, the amount of K applied was approximately $1846 \mathrm{~kg} \mathrm{ha}^{-1}$. In Southern Sweden, moderate doses of $\mathrm{N}$-free fertilizer like $\mathrm{K}$ are not likely to drastically affect the community structure of the dominating ectomycorrhizal fungi (Kårén and Nylund 1996). In our research, amount of K exceed this dose over 40 times, and according to the Swedish study, the effect on fungi in the studied area should be negative. There are similar differences between amounts of nitrogen applied; published application rates vary from 30 to $50 \mathrm{~kg} \mathrm{ha}^{-1}$ at the time of planting to $100-300 \mathrm{~kg} \mathrm{ha}^{-1}$ for established forests (Binkley et al. 1994). In our research, the application of $\mathrm{N}$ varied from 176 to $1325 \mathrm{~kg} \mathrm{ha}^{-1}$ depending upon year. The volume of water applied decreased from 1999 with no change in amount of $\mathrm{N}$, causing a higher concentration and, as a consequence, a growth decline (Fig. 4). The negative effect may result from mycorrhiza suppression. Some ectomycorrhizal symbiotic fungi inhibit pathogens (Rudawska 1990), probably due to metabolites produced by symbiotic fungi and synthesized in roots (Oleksyn 1998). Symbionts seem to be sensitive to the high amount of $\mathrm{N}$ applied (Wallenda and Kottke 1998). Some other research point out the negative influence of fertilization, negative effect of high fertilization is the decrease tree resistance to insects (Glynn and Herms 2001).
In this research, we applied chlorophyll fluorescence to investigate if plant tolerance to environmental inducted stress was related to the tree physiological condition of the tree (Maxwell and Johnson 2000; Pukacki 2000; Kalaji and Guo 2008; Roháček et al. 2008; Kalaji et al. 2011, 2014). According to Koehn et al. (2003) healthy unstressed pine plants are characterized by $\mathrm{Fv} / \mathrm{Fm}$ value of about $0.84 \mathrm{r}$. u. Weng et al. (2006) observed that Fv/Fm values of two pine species remained high in the warmer season and declined to $0.6 \mathrm{r}$. u. in the cooler season. This observation is in accordance with studies of Pukacki (2000), in which the $\mathrm{Fv} / \mathrm{Fm}$ ratio was proven to decrease from 0.83 to 0.62 in some pine population in Poland during winter.

A decrease in $\mathrm{Fv} / \mathrm{Fm}$ value usually means that the plant has been exposed to a stress factor (Maxwell and Johnson 2000; Kalaji and Guo 2008). In this study, we focused on the parameter $\mathrm{Fv} / \mathrm{Fm}$, which is one of the parameters providing information about the fundamental processes which have altered photosynthesis efficiency (Figs. 5, 6). A change in $\mathrm{Fv} / \mathrm{Fm}$ is due to a change in the efficiency of non-photochemical quenching. Values of the Fv/Fm measured in dark-adapted samples reflect the potential quantum efficiency of PSII. Our results confirmed that this parameter is a sensitive indicator of plant photochemical performance (Björkman and Demmig 1987; Johnson et al. 1993; Maxwell and Johnson 2000; Pukacki 2000; Roháček et al. 2008; Koehn et al. 2003). However, it seems to be that Area parameter, which expresses the size of the reduced plastoquinone pool, was the most affected one (Fig. 6).

This study shows that trees fertilized with effluents from a nearby factory producing potato starch had an initial increase in growth (1984-1999) compared to unfertilized and control trees. However, once the concentrations of N, P and $\mathrm{K}$ were increased in the effluent (2000-2012) it caused a growth decrease and a weakening of physiological condition of the trees. The change in physiological condition can be a result of nutritional imbalance in other necessary for photosynthesis and growth nutrients and provoked osmotic stress in soil caused by the high level of nutrients itself (Elliott and White 1994). The former affects the photosynthetic nutrient use efficiency (Thomas et al. 1994), whilst the latter provides to limitation of stomata opening, and thus, photosynthesis of trees decreases (Broeckx et al. 2014). The stomatal closure limits the $\mathrm{CO}_{2}$ uptake. This, in return, might promote an imbalance between the photochemical activity at photosystem II (PSII) and the electron requirement for photosynthesis generating an over-excitation on photosynthetic system and the photoinhibitory damages of PSII reaction centres (Souza et al. 2004). These results confirm that application of $\mathrm{N}, \mathrm{P}$ and $\mathrm{K}$ at highly elevated levels is detrimental to the health of the forest and is not a suitable method of waste management. Nowadays, 
the Iława Forest Inspectorate is trying to restore the forest to former conditions, but some parts will be maintained as a research area to study the recovery of the forest. Our results also confirm that, the measurement of chlorophyll fluorescence is an effective measure of the physiological status of trees affected by $\mathrm{N}, \mathrm{P}$ and $\mathrm{K}$ fertilization.

Author contribution statement Marcin Koprowski, conception and design; fieldwork; analysis and interpretation; statistical analysis; writing the article. Iain Robertson, fieldwork; analysis and interpretation; critical revision of the article. Hazem M. Kalaji, analysis and interpretation; statistical analysis; writing the article. Tommy $\mathrm{H}$. G. Wils, fieldwork; analysis and interpretation; final approval of the article

Acknowledgments This research is linked to activities conducted within the COST FP1106 network. Iain Robertson acknowledges support from the Climate Change Consortium of Wales and a Research Fellowship within the project "Enhancing Educational Potential of Nicolaus Copernicus University in the Disciplines of Mathematical and Natural Sciences" (Project No. POKL.04.01.0100-081/10). The authors would like to thank Anna Krzyżanowska the head of Ilawa Forest District for permission of doing research, the forester Zbigniew Treder for shooting branches and Arkadiusz Marszałek from Chemirol Company for providing us with necessary data. This work was partially supported by the National Centre for Research and Development (NCBiR), Poland, Grant: Biostrateg-I/ $2489 / 2014$.

Conflict of interest The authors declare that they have no conflict of interest.

Open Access This article is distributed under the terms of the Creative Commons Attribution 4.0 International License (http:// creativecommons.org/licenses/by/4.0/), which permits unrestricted use, distribution, and reproduction in any medium, provided you give appropriate credit to the original author(s) and the source, provide a link to the Creative Commons license, and indicate if changes were made.

\section{References}

Binkley D, Carter R, Allen HL (1994) Nitrogen fertilization practices in forestry. In: Becon P (ed) Nitrogen fertilization in the environment. CRC Press, New York, Basel, Hong Kong, pp 421-441

Björkman O, Demmig B (1987) Photon yield of $\mathrm{O}_{2}$ evolution and chlorophyll fluorescence at $77 \mathrm{k}$ among vascular plants of diverse origins. Planta 170:489-504

Briffa K, Schweingruber FH, Jones PD, Osborn T, Harris I, Shiyatov S, Vaganov A, Grudd H (1998) Trees tell of past climates: but are they speaking less clearly today? Philos Trans B 353:65-73

Broeckx LS, Fichot R, Verlinden MS, Ceulemans R (2014) Seasonal variations in photosynthesis, intrinsic water-use efficiency and stable isotope composition of poplar leaves in a short-rotation plantation. Tree Physiol 34(7):701-715

Bunn AG (2008) A dendrochronology program library in R (dplR). Dendrochronologia 26:115-124

Ciepielowski A, Gumnicka O, Krajewski T (1999) Wpływ Leśnej Oczyszczalni Ścieków w Iławie na Środowisko leśne. In: Ciepielowski A (ed.) Problemy oczyszczania ścieków w środowisku leśnym. Materiały Seminarium Naukowego. Manuscripts of the Forest Research Institute, Warszawa pp 9-19
Cook ER, Briffa K, Shiyatov S, Mazepa A, Jones PD (1990) Data analysis. In: Cook ER, Kairiukstis LA (eds) Methods of dendrochronology: applications in the environmental sciences. Kluwer Academic Publishers, Dodrecht, pp 97-162

D'Arrigo R, Wilson R, Liepert B, Cherubini P (2008) On the "divergence problem" in northern forests: a review of the treering evidence and possible causes. Glob Planet Change 60:289-305

Elhani S, Guehl J-M, Nys C, Picard J-F, Dupouey J-L (2005) Impact of fertilization on tree-ring $15 \mathrm{~N}$ and $13 \mathrm{C}$ in beech stands: a retrospective analysis. Tree Physiol 25:1437-1446

Elliott KJ, White AS (1994) Effects of light, nitrogen, and phosphorus on red pine seedling growth and nutrient use efficiency. For Sci 40(1):47-58

Fox TR, Allen HL, Albaugh TJ, Rubilar R, Carlson CA (2007) Tree nutrition and forest fertilization of pine plantations in the southern United States. South J Appl For 31:5-11

Glynn C, Herms DA (2001) Effects of nitrogen fertilization on forest trees in relation to insect resistance and red-listed insect species. Forestry Research Institute of Sweden. Report No. 3:1-39

Hawelke P, Sokołowski J (1999) Oczyszczanie ścieków na terenach rolniczych na przykładzie obiektu łąkowego Kupiski-Jednaczewo. In: Ciepielowski A (ed.) Problemy oczyszczania ścieków w środowisku leśnym. Materiały Seminarium Naukowego. Manuscripts of the Forest Research Institute, Warszawa, pp 29-37

He J, Chee CW, Goh CJ (1996) 'Photoinhibition' of Heliconia under natural tropical conditions: the importance of leaf orientation for light interception and leaf temperature. Plant Cell Environ 19:1238-1248

Holmes RL (1983) Computer-assisted quality control in tree-ring dating and measurement. Tree-Ring Bulletin 43:69-78

Johnson GN, Young AJ, Scholes JD, Horton P (1993) The dissipation of excess excitation energy in British plant species. Plant Cell Environ 16:673-679

Kalaji MH, Guo P (2008) Chlorophyll fluorescence: a useful tool in barley plant breeding programs. In: Sanchez A, Gutierrez SJ (eds) Photochemistry research progress. Nova Publishers, New York, pp 439-463

Kalaji MH, Bosa K, Kościelniak J, Hossain Z (2011) Chlorophyll a fluorescence-a useful tool for the early detection of temperature stress in spring barley (Hordeum vulgare L.). OMICS J Integr Biol 15:925-934

Kalaji MH, Goltsev V, Bosa K, Allakverdiev SI, Strasser RJ, Govindjee (2012) Experimental in vivo measurements of light emission in plants: a perspective dedicated to David Walker. Photosynthesis Res 114:69-96

Kalaji MH, Schansker G, Ladle RJ, Goltsev V, Bosa K, Allakhverdiev SI, Brestic M, Bussotti F, Calatayud A, Dąbrowski P, Elsheery NI, Ferroni L, Guidi L, Hogewoning SW, Jajoo A, Misra AN, Nebauer SG, Pancaldi S, Penella C, Poli DB, Pollastrini M, Romanowska-Duda ZB, Rutkowska B, Serôdi J, Suresh K, Szulc W, Tambussi E, Yanniccari M, Zivcak M (2014) Frequently asked questions about in vivo chlorophyll fluorescence: practical issues. Photosynth Res 122(2):121-158

Kårén O, Nylund J-E (1996) Effects of N-free fertilization on ectomycorrhiza community structure in Norway spruce stands in Southern Sweden. Plant Soil 181:295-305

Koehn AC, Roberds JH, Doudrick L (2003) Variation among slash pine families in chlorophyll fluorescence traits. Can J For Res 33:1102-1109

Koprowski M (2013) Spatial distribution of introduced Norway spruce growth in lowland Poland: the influence of changing climate and extreme weather events. Quatern Int 283:139-146

Koprowski M, Przybylak R, Zielski A, Pośpieszyńska A (2012) Tree rings of Scots pine (Pinus sylvestris L.) as a source of 
information about past climate in northern Poland. Int $\mathrm{J}$ Biometeorol 56:1-10

Kowalczewski P, Celka K, Białas W, Lewandowicz G (2012) Antioxidant activity of potato juice. Acta Scientiarum Polonorum, Technologia Alimentaria 11(2):175-181

Kowalczewski P, Sip A, Lewandowicz G (2014) Antimicrobial activity of potato juice. Postępy Techniki Przetwórstwa Spożywczego [Progress in Food Processing Technology] 24/45(2):56-61

Larsson L-A, Larsson PO (2013) CDendro and CooRecorder, version 7.3, http://www.cybis.se. Accessed 30 May 2015

Luo Y, Su B, Currie WS, Dukes JS, Finzi A, Hartwig U, Hungate B, McMurtrie RE, Oren R, Parton WJ, Pataki DE, Shaw R, Zak DR, Field CB (2004) Progressive nitrogen limitation of ecosystem responses to rising atmospheric carbon dioxide. Bioscience 54:731-739

Maxwell K, Johnson GN (2000) Chlorophyll fluorescence-a practical guide. J Exp Botany 51:659-668

Mayer F, Hillebrandt JO (1997) Potato pulp: microbiological characterization, physical modification, and application of this agricultural waste product. Appl Microbiol Biotechnol 48:435-440

Mellert KH, Prietzel J, Straussberger R, Rehfuess KE (2004) Longterm nutritional trends of conifer stands in Europe: results from the RECOGNITION project. EurJ For Res 123:305-319

Moller G (1992) The Scandinavian experience in forest fertilization research and operations. In: Chappel HN, Weetman GF, Miller RE (eds) Forest fertilization: sustaining and improving nutrition and growth of western forests. College of Forest Resources, University of Washington, USA, pp 251-259

Oleksyn J (1998) Fizjologia. In: Białobok S, Boratyński A, Bugała W (eds) Biologia sosny zwyczajnej. Polska Akademia Nauk, Instytut Dendrologii, Sorus, Poznań-Kórnik, pp 89-207

Opała M, Mendecki MJ (2014) An attempt to dendroclimatic reconstruction of winter temperature based on multispecies tree-ring widths and extreme years chronologies (example of Upper Silesia, Southern Poland). Theor Appl Climatol 115:73-89

Peters H (1972) Measures taken against water pollution in starch and potato processing industries. Pure Appl Chem 29:129-141

Pukacki PM (2000) Effects of sulphur, fluoride and heavy metal pollution on the chlorophyll fluorescence of Scots pine (Pinus sylvestris $\mathrm{L}$ ) needles. Dendrobiology 45:83-88

Reich PB, Hobbie SE, Lee T, Ellsworth DS, West JB, Tilman D, Knops JMH, Naeem S, Trost J (2006) Nitrogen limitation constrains sustainability of ecosystem response to $\mathrm{CO}_{2}$. Nature 440:922-925

R Development Core Team (2007) R: a language and environment for statistical computing R Foundation for Statistical Computing, Vienna, Austria ISBN 3-900051-07-0. http://wwwR-project.org

Roháček K, Soukupová J, Barták M (2008) Chlorophyll fluorescence: a wonderful tool to study plant physiology and plant stress. Plant Cell compartments-selected topics, Research Signpost, pp 41-104
Rudawska M (1990) Some mechanisms of resistance of mycorrhizae to pathogenic infections. Finnish Forest Research Institute Research Papers, pp 191-199

Sasim M, Mierkiewicz M (2005) Susza w 2003. Gazeta Obserwatora IMGW 1:37-38

Smethurst PJ (2010) Forest fertilization: trends in knowledge and practice compared to agriculture. Plant Soil 335:83-100

Souza RP, Machado EC, Silva JAB, Lagoa AMMA, Silveira JAG (2004) Photosynthetic gas exchange, chlorophyll fluorescence and some associated metabolic changes in cowpea (Vigna unguiculata) during water stress and recovery. Environ Exp Bot $51: 45-56$

Stokes MA, Smiley TL (1968) An introduction to tree-ring dating. University of Arizona Press, Tucson, p 73

Strasser RJ, Tsimilli-Michael M, Srivastava A (2004) Analysis of the chlorophyll a fluorescence transient. In: Papageorgiou GC, Govindjee (eds) Chlorophyll a fluorescence a signature of photosynthesis. Springer, Dordrecht, pp 321-362

Szychowska-Krapiec E (2010) Long-term chronologies of pine (Pinus sylvestris L) and fir (Abies alba Mill) from the Małopolska Region and their paleoclimatic interpretation Folia Quat 79:5-124

Thomas RB, Lewis JD, Strain BR (1994) Effects of leaf nutrient status on photosynthetic capacity in loblolly pine (Pinus taeda L.) seedlings grown in elevated atmospheric $\mathrm{CO}_{2}$. Tree Physiol 14:947-960

Valladares F, Pearcy RW (1997) Interactions between water stress, sun-shade acclimation, heat tolerance and photoinhibition in the sclerophyll Heteromeles arbutifolia. Plant Cell Environ 20:25-36

Vitas A (2002) Drought of 1992 in Lithuania and consequences to Norway spruce. Balt For 7:25-30

Vlachojannis JE, Cameron M, Chrubasik S (2010) Medicinal use of potato-derived products: a systematic review. Phytother Res 24:159-162

Wallenda T, Kottke I (1998) Nitrogen deposition and ectomycorrhizas. New Phytol 139:169-187

Weng JH, Liao TS, Hwang MY, Chung CC, Lin CP, Chu CH (2006) Seasonal variation in photosystem II efficiency and photochemical reflectance index of evergreen trees and perennial grasses growing at low and high elevations in subtropical Taiwan. Tree Physiol 26:1097-1104

Wigley T, Briffa KR, Jones PD (1984) On the average value of correlated time series, with applications in dendroclimatology and hydrometeorology. J Appl Meteorol Climatol 23:201-213

Zang C, Biondi F (2013) Dendroclimatic calibration in R: the bootRes package for response and correlation function analysis. Dendrochronologia 31:68-74

Zielski A, Krạpiec M (2004) Dendrochronologia. Wydawnictwo Naukowe PWN, Warszawa, pp 1-328

Zielski A, Krąpiec M, Koprowski M (2010) Dendrochronological data. In: Przybylak R, Majorowicz J, Brázdil R, Kejna M (eds) The polish climate in the European context: an historical overview. Springer, Berlin, Heidelberg, New York, pp 191-217 